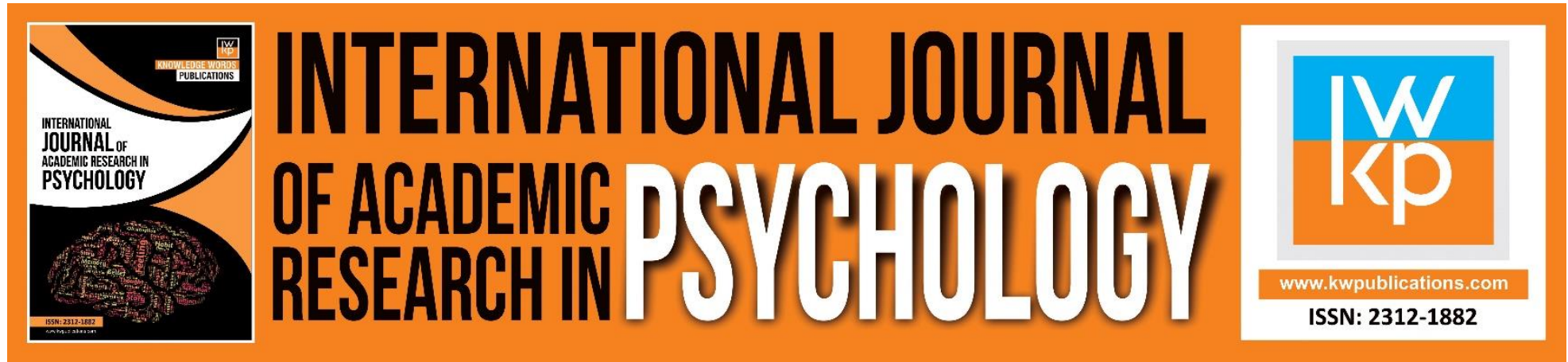

\title{
Psychosocial Determinants of Identified Adolescents, Addictive Behaviors in Ado-Ekiti Local Government Area of Ekiti State
}

Falana, Bernard Akinlabi, Fasina, Bosede Oluwayemisi

To Link this Article: http://dx.doi.org/10.46886/IJARP/v1-i1/1309

DOI:10.46886/IJARP/v1-i1/1309

Received: 08 June 2014, Revised: 23 August 2014, Accepted: 16 September 2014

Published Online: 29 September 2014

In-Text Citation: (Falana \& Fasina, 2014)

To Cite this Article: Falana, B. A., \& Fasina, B. O. (2014). Psychosocial Determinants of Identified Adolescents, Addictive Behaviors in Ado-Ekiti Local Government Area of Ekiti State. International Journal of Academic Research in Psychology, 1(1), 35-42.

Copyright: (C) 2014 The Author(s)

Published by Knowledge Words Publications (www.kwpublications.com)

This article is published under the Creative Commons Attribution (CC BY 4.0) license. Anyone may reproduce, distribute, translate and create derivative works of this article (for both commercial and non-commercial purposes), subject to full attribution to the original publication and authors. The full terms of this license may be seen

at: http://creativecommons.org/licences/by/4.0/legalcode

Vol. 1, No. 1, 2014, Pg. 35 - 42

https://kwpublications.com/journals/journaldetail/IJARP

JOURNAL HOMEPAGE

Full Terms \& Conditions of access and use can be found at https://kwpublications.com/pages/detail/publication-ethics 


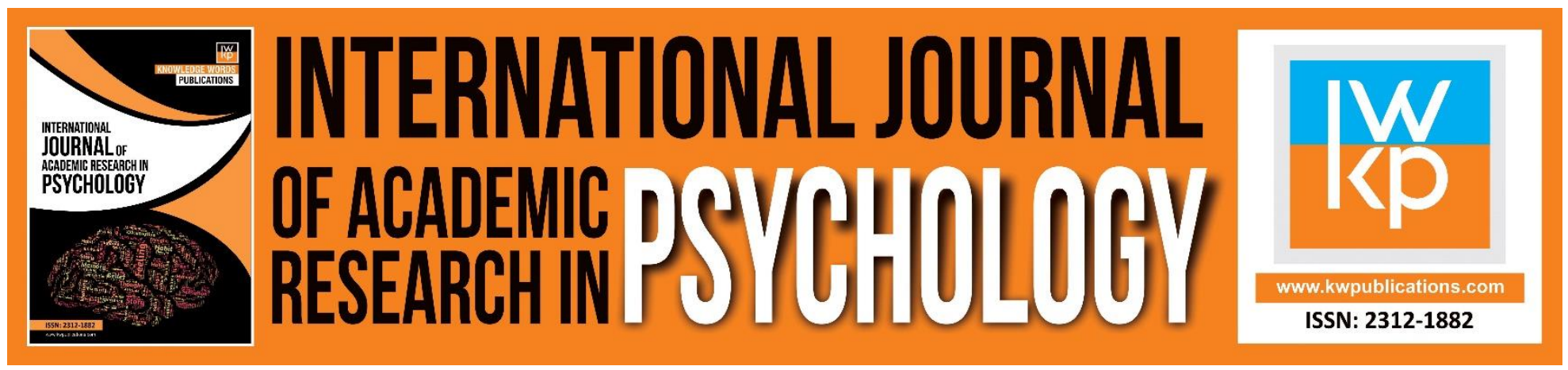

\title{
Psychosocial Determinants of Identified Adolescents, Addictive Behaviors in Ado-Ekiti Local Government Area of Ekiti State
}

\author{
Falana, Bernard Akinlabi (Phd), Fasina, Bosede Oluwayemisi \\ Department of Guidance and Counseling, Faculty of Education, Ekiti State University, Ado-Ekiti \\ Email: falana2010@yahoo.com
}

\section{Abstract}

The study investigated the psychosocial determinants of identified addictive behaviours of adolescents in Ado Ekiti Local Government. The researcher employed the usage of descriptive research design of the survey type. The population for the study involves all the adolescents in Ado Ekiti Local Government Area of Ekiti State, Nigeria. A self designed research instrument titled "Addictive Behaviour Questionnaire" (ABQ) was used for gathering data. Experts in the Departments of Guidance and Counselling, Human Kinetics and tests and measurement ensured the validity of the instrument. A reliability coefficient of 0.75 was obtained using test-retest reliability and Pearson product moment correlation analysis. Copies of the instrument was personally administered by the researcher.

The data generated were analysed using inferential statistics of t-test and analysis of variance. It was revealed that the family structure and economic status of adolescents significantly influence their addictive behaviours. Based on these findings parents should ensure that there is cohesion and stability in their homes to discourage adolescents involvement in addictive behaviours. Also parents, guardians, and all the stakeholders in the upbringing of adolescents should make adequate provision for the needs of adolescents to enhance their development of good identity. However this study could be of benefits to male and female adolescents, parents, teachers, counsellors, curriculum planners, caregivers, health care practitions and stakeholders in the upbringing of adolescents.

Keywords: Psychological, Determinants, Adolescents, and Addictive Behaviours.

\section{Introduction}

Adolescence is a transitional period in the human life span, it is a linkage of childhood to adulthood. Puberty is the onset of adolescents. It is a period of rapid physical maturation involving hormonal and bodily changes that occur during early adolescence. This puberty attainment is determined by nutrition, health, heredity and body mass. Archibald, Graber and Brooks-Gun (2003) observed that puberty is not a single, sudden event. Puberty is the evidence that a young girl and boy 
INTERNATIONAL JOURNAL OF ACADEMIC RESEARCH IN PSYCHOLOGY

Vol. 1, No. 1, 2014, E-ISSN: 2312-1882 @ 2014 KWP

is experiencing developmental changes. Whenever young girls and boys are at the spurt of growth (Puberty) there are changes in growth such as hormonal changes. This is experienced in hypothalamus, pituitary and the gonads. The concentration of hormones spontaneously increases during adolescence (Auchus \& Rainey, 2004; Susman, Dorn \& Schiefelbein 2003; Susman \& Rogol 2004).

Accompanied with the hormonal increament and changes are increament in height, weight and sexual maturation. The rate at which adolescents gain weight follows approximately the same developmental timetable as the rate at which they gain height. Marked weight gains coincide with the onset of puberty. During early adolescence girls tend to outweigh boys, but just as with height, but by about age 14 boys begin to surpass girls. Also at the onset of puberty male pubertal characteristics develop by increament in penis, testicle size, straight pubic hair, minor voice change, first ejaculation, onset of maximum growth, appearance of hairs in the armpits and growth of facial hair, this is accompanied by height spurt in female they experience breast enlargement or pubic hair, hairs appear at the armpits, there is marked growth in height, widened hip and menstruation begins. The girls experiences erratic menstrual cycle, some girls don't ovulate at all until a year or two after menstruation begins. By the end of puberty the females breast have become more fully rounded.

All these changes in body image makes adolescents to be preoccupied with their bodies and develop individual images of what their bodies are like. All these makes the boys and girls to look at mirrors on a daily and even hourly basis to investigate if they could still detect different structures that are changing in their bodies. These preoccupation with ones body image is strong throughout adolescence but it is acute during puberty. This is a time when adolescents are more dissatisfied with their bodies than in late adolescence (Graber \& Brooks - Gunn, 2001; Wright, 1989).

There are gender differences in adolescents' perception of their bodies. In general girls are less happy with their bodies and have more negative body images, compared with boys feelings about their bodies (Brooks-Gunn \& Paikoff, 1993). As pubertal change proceeds, girls often become more dissatisfied with their bodies, this may be as a result of increase in body fat whereas boys become more satisfied as they move through puberty, probably because their muscle mass increases (Gross, 1984).

Adolescence is not a time of rebellion, crisis, pathology and deviance. It is a time of evaluation, of decision making of commitment, of carrying out a place in the world. As adolescents are progressing in their development they tend to face various emotional challenges. These are exemplified in various ways such as sexuality, having sexual identity, risk factors for sexual problems usage of contraceptives, substance use and abuse, health challenges risk taking behaviour and in most cases death of adolescents.

Sexual development and interest in sex are normal aspects of adolescent development and majority of adolescents have healthy sexual attitudes and engage in sexual practices that will not compromise their development. The sophisticated media, especially television teaches adolescents about sex (Collins, 2004; Galician, 2004; Gruber \& Gruber, 2000; Ward \& Caruthers, 2001). Adolescents are exposed to explicit sex in TV shows and videos, lyrics of music, internet websites (Roberts, Henrikson \& Foehr, 2004). Ward (2003) reported that frequent watching of soap operas and music videos were linked with greater acceptance of casual attitudes about sex and higher expectations of engaging in sexual activity. Adolescence being a period of sexual exploration and experimentation, of sexual fantasies and realities, of incorporating sexuality into ones identity 
adolescents have an almost insatiable curiosity about sexuality mysteries. They think about whether they are sexually attractive how to do sex and what the future holds for their sexual lives. The majority of adolescents eventually manage to develop a mature sexual identity, but most experience times of vulnerability and confusion along life's sexual journey. All these maybe accountable for the crime of sexual violence pervading Nigeria. This is evidence in the cases of adolescence, sexual harassment, embarrassment and rape pervading Nigeria society.

Most adolescents become sexually active at some point during adolescence, some adolescents engage in sex at early ages before age 16 and experience a number of partners over time (Cavanaugh, 2004). These adolescents are the least effective users of contraception and are at risk for early, unintended pregnancy and for sexually transmitted infections. Early sexual activity is linked with other risky behaviours such as excessive drinking, drug use, delinquency and school related problems (Dryfoos, 1990) adolescents who live in low-income neighborhoods often are more sexually active and have higher adolescent pregnancy rates than adolescents who live in more affluent circumstances. This may be accountable for the higher rate of teenage pregnancy and motherhood in Nigeria. The precarious issue of baby homes operating in various part of Nigeria is a strong reason. The issue of self-regulation is another significant factor. The ability to regulate ones emotions and behaviour and parents-adolescents relationships are strong factors in controlling adolescents sexual behaviour. Rafaelli and Crockett (2003) in a longtitudinal study conducted reported that a lower level of self-regulation at 12 to 13 years of age was linked with a higher level of sexual risk taking four years later. Other researchers such as Kahn, Rosenthal, Succop, Ho, Ho and Burk (2002) found a relation between low self regulation and high sexual risk. Huebuar and Howell (2003) reported that sexual risk taking in adolescence was related to low parental monitoring and poor parent-adolescent communication.

On the issue of sexually transmitted infections (STIs), yearly 3million American adolescents (about one-fourth of those who are sexually experienced) acquire an STI (Centers for Disease Control and Prevention 2014). In a simple act of unprotected sex with an infected partner, a teenage girl has a 1 percent risk of getting HIV, a 30 percent risk of acquiring genital herpes and a 50 percent chance of contracting gonorrhea (Gler, 1999).

The developmental changes occurring in adolescents heralds the various behaviours of substance use and abuse. Once adolescents begin to take drug, drink alcohol and smoke cigarette, the addictive properties in these substances becomes extremely difficult to stop. Tucker, Ellickson \& Klein (2003) reported that the risk factor of becoming a smoker are; having a friend who smoked having a weak academic orientation and experiencing low parental support. Thuston et al (1999) observed that smoking in the adolescent years causes permanent genetic changes in the lungs and forever increases the risk of lung cancer even if the smoker quits. The damage was much less likely among smokers in the study who started in their twenties. It was evident in the study that the early age of onset of smoking was more important in predicting genetic damage than how much the individuals smoked. Researchers have equally found that drug use in childhood or early adolescence has more detrimental long-term effects on the development of responsible, competent behaviour than when drug use occurs in late adolescence (Newcomb and Bentler, 1989) when adolescents use drugs to cope with stress, many young adolescents enter adult roles of marriage and work prematurely without adequate socio emotional growth and experience greater failure in adult roles. 
Parents, peers and social support is important in preventing adolescents drug abuse (Hotton and Hans 2004; Wood and Fletcher, Stemberg and Williams-Wheeler (2004) reported that parental control and monitoring were linked with a lower incidence of problem behaviour by adolescents including substance abuse. Low parental involvement, peer pressure and associating with problembehaving friends were linked with higher use of drugs by adolescents (Simons-Mortion et al., 2001).

Also parents who were more involved in setting limits such as where adolescents went after school and what they were exposed to on TV and the internet, were more likely to have adolescents who did not use drugs (National Center for Addiction and Substance Abuse, 2001).

\section{Research Rationale}

There are reports on daily bases by casual observers, on radio, in print media and sophisticated electronics media about adolescents addictive behaviours such as what sexual behaviours like sexual promiscuity, harassment, coercion and a host of indecent sexual acts. Also there are report on adolescents abusing and misuse of substance, all these appears to be posing challenges of risk taking behaviours. All these misdemeanors experienced in various sectors of Nigeria appears to corroborate biological and psychological factors of developmental changes of these miniature adolescents. These hormonal increament that accompanies increament in height, weight and sexual maturation seems to be accountable for most of the illicit behaviours pervading Nigeria society. The psychological and sociological factors in the environment such as location of adolescents, parents, peer relationship cum adolescents relationship with parents and guardian could speak for the spate of addictive behaviours accountable for violence and restiveness rocking Nigeria. It appears as if most of these adolescents are acting under the influences of misuse of substances like alcohol and drug. These may be accountable for hydraheaded demon of violence defiling all weapons of sanitation in Nigeria.

The precarious situation of the prevalence of divorce, instability of homes, irregular distribution of wealth in Nigeria may be responsible for the adolescents addiction to heinous crimes in places like Ekiti State, Nigeria.

\section{Methodology}

The researcher made use of the descriptive research design of the survey type. The population for the study was made up of all the adolescents in Ado-Ekiti local government area of Ekiti State, Nigeria. 150 adolescents were randomly selected using multistage sampling techniques also involving stratified sampling technique. A research instrument titled "Addictive Behaviour Questionnaire" (ABQ) was used for gathering data. The face and content validities of the instrument was ensured through experts in Human Kinetics, tests and measurement and guidance and counselling departments. The reliability coefficient of the instrument was estimated at 0.75 using test retest reliability method and Pearson product moment correlation analysis. The data generated were analysed using inferential statistics. The hypothesis postulated was tested using inferential statistics of t-test and Analysis of Variance (ANOVA).

Hypothesis 1: Adolescents family structure will not significantly influence their addictive behaviour

2. Adolescents economic status will not significantly influence their addictive behaviour.

\section{Hypothesis 1}


INTERNATIONAL JOURNAL OF ACADEMIC RESEARCH IN PSYCHOLOGY

Vol. 1, No. 1, 2014, E-ISSN: 2312-1882 @ 2014 KWP

Table 1: t-test analysis of family structure and adolescent's addictive behaviour

\begin{tabular}{|c|c|c|c|c|c|}
\hline Group & Mean & S.D & df & tcal & t-table \\
\hline Stable & 31.47 & 2.66 & & & \\
\hline Unstable 103 & 33.71 & 2.42 & 1.48 & 5.103 & 1.960 \\
\hline
\end{tabular}

$P<0.05$

Table 1 shows that $t-c a l$ (5.103) is greater than t-table (1.960) at 0.05 level of significance. The null hypothesis adolescents family structure will not significantly influence adolescents addictive behaviour is rejected. This implies that family structure of adolescents will significantly influence their addictive behaviour.

Table 2: Oneway ANOVA of adolescent's economic status and addictive behaviour

\begin{tabular}{|l|l|l|l|l|l|}
\hline Source & Ss & df & Ms & t-cal & t-table \\
\hline Between Groups & 627.85 & 2 & 313.92 & & \multirow{3}{*}{3.04} \\
\cline { 1 - 3 } Within Groups & 455.15 & 147 & 3.096 & & \\
\hline Total & 1082.99 & 149 & & & \\
\hline
\end{tabular}

$\mathrm{P}<0.05$

Table 2 shows that $t$-cal (101.39) is greater than t-table (3.04) at 0.05 level of significance. The null hypothesis adolescent economic status will not significantly influence adolescents addictive behaviour is rejected.

\section{Discussion}

The finding family structure of adolescent significantly influence their addictive behaviour was in agreement with; Allen, Hausen Borman-Spurrell (1996) finding, that securely attached adolescents were less likely than those who were insecurely attached to engage in addictive and problem behaviours such as juvenile delinquency and drug abuse also Kobak (1999); Laibe, Carlo and Raffaeli (2000) reported that securely attached adolescents had better peer relations than their insecurely attached counterparts.

Also the findings economic status of adolescents significantly influence adolescents addictive agrees with the report of Council of Economic Advisors (2000) that adolescents who did not eat dinner with a parent five or more days a week had dramatically higher rates of smoking, drinking marijuana use, getting into fights and initiation of sexual activity. Mounts (2002) reported that parents who played an active role in monitoring and guiding their adolescents development were more likely to have adolescents with positive peer relations and lower drug use than parents who had a less active role.

\section{Recommendations}

Based on the findings it is recommended that parents should endeavour to enhance stability in their homes to enhance proper development of adolescents and reduce addictive behaviour. Parents and adolescents care givers should make provision for the financial needs of the adolescents to ensure their security and identity needs. This will reduce the addictive related peer influences and prevent them from seeking solace in external influences that could be injurious to their development. 
INTERNATIONAL JOURNAL OF ACADEMIC RESEARCH IN PSYCHOLOGY

Vol. 1, No. 1, 2014, E-ISSN: 2312-1882 @ 2014 KWP

\section{Significance of the Study}

This study could benefit the would be adolescents, adolescent parents, guardians, students teachers, counsellors school administrators, proprietors, curriculum planners and adolescents care givers. The would be adolescents and adolescents could learn and understand their challenges and coping mechanisms for these challenges. Parents, guardians, teachers and counsellors could understand learn, teach and counsel these adolescents about the determinants of addictive behaviours and provide coping mechanisms for these challenges to live a healthy life. The curriculum planners could incorporate areas that would benefit the students to the national curriculum to be implemented by school administrators and school proprietors across the three tiers of government in Nigeria.

\section{References}

Allen, J. P., Hauser, S. T., \& Borman, Spurrell, E. (1996). Attachment security and related sequelae of severe adolescent. Psychopathology; An eleven-year follow-up study. Journal of Consulting and Clinical Psychology, 64, 254-263.

Archibald, A. B., Graber, J. A., \& Brooks - Grunn, J. (2003). Pubertal processes and physical growth in adolescence. In G.R. Adams \& M. Berzoinky, (Eds), Handbook on adolescence. Malden MA: Blackwell.

Auchus, R. J., \& Rainey, W. E. (2004). Adrenarche-physiology, biochemistry and human disease, clinical endocrinology 60, 288-296.

Brooks-Gunn, J., \& Paikoff, R. (1993). Sex is a gamble, kissing is a game: Adolescence sexuality, contraception, and sexuality. In S.P. Millstein, A.C. Peterson, \& E.O. Nightingale (Eds). Promoting the health behaviour of adolescents New York: Oxford University Press.

Cavanugh, S. E. (2004). The sexual debut of girls in adolescence: The intersection of race pubertal timing and friendship group characteristics. Journal of Research on Adolescence, 14, 285-312.

Centers for Disease Control and Prevention. (2004). Sexually transmitted diseases Atlanta: Author.

Council of Economic Advisors. (2000). Teens and their parents in the $21^{\text {st }}$ century: An examination of trends in teen behaviour and the role of parent involvement. Washington, DC: Author.

Dryfoos, J. G. (1990). Adolescents at risk: prevalence or prevention. New York: Oxford University Press.

Fletcher, A. C., Steinberg, L., \& Williams-Wheeler, M. (2004). Parental influences on adolescent problem behaviour. Revisiting station and Kern. Child development 75, 781-796.

Galician, M. L. (2004). Sex, love and romance in the mass media. Mahwah, N.J., Erlbaum.

Glei, D. A. (1999). Measuring contraceptive use patterns among teenage and adult woman. Family planning perspectives, 31, 73-80.

Grabber, J. A., \& Brooks-Gunn, J. (2002). Adolescent girls sexual development. In G.M. Wingood \& R.J. Diclemente (Eds), Handbook of sexual and reproductive health New York: Plenum.

Gross, R. T. (1984). Patterns of maturation: Their effects on behaviour and development. In M.D. Levine \& P. Satz (Eds), Middle.

Gruber, E., \& Gruber, J. W. (2000). Adolescent sexuality and the media; A review of current knowledge and implications, Western Journal of Medicine 172, 210-214.

Hotton, T., \& Hanns, D. (2004). Alcohol and drug use in early adolescence. Health reports 15, 9-19. 
Huebner, A. J., \& Howell, L. W. (2003). Examining the relationship between adolescent sexual risktaking and perceptions of monitoring, communication and parenting styles. Journal of Adolescent Health 33, 71-78.

Kahn, J. A., Rosenthal, S. O., Succop, P. A., Ho, P. A., Ho, G. Y., \& Burk, R. D. (2002). The interval between menache and age of first sexual intercourse as a risk factor for subsequent HPV infection in adolescent and young adult women. Journal of pediatrics. 141, 718-723.

Kobak, R. (1999). The emotional dynamics of disruptions in attachment relationships: implications for theory, research and clinical intervention. In J. Cassidy \& P. Shaver (Eds.), Handbook of attachment, New York: Guilford.

Laiber, D. J., Carlo, G., \& Raffaeli, M. (2000). The differential relations of parent and peer attachment to adolescent adjustment. Journal of Youth and Adolescence. 29, 45-53.

Mounts, N. S. (2002). Parental management of adolescents peer relationships in context: The role of parenting style. Journal of Family Psychology, 16, 58-69.

National Center for Addiction and Substance Abuse. (2001). 2000 teen survey. New York: National Center for Addiction and Substance Abuse, Columbia University.

Newcounts, M. D., \& Bentler, P. M. (1989). Substance use and abuse among children and teenagers. American psychologist 44, 242-248.

Rafaelli, M., \& Crockett, L. J. (2003). Sexual risk taking in adolescence: The role of self-regulation and attraction to risk. Developmental psychology. 39, 1036-1046.

Roberts, D. F., Henriksen, L., \& Foehr, V. G. (2004). Adolescents and the media. In R. Lerner \& L. Steinberg (Eds), Handbook of adolescent psychology New York: Willey.

Simons-Morton, B., Haynie, D. L., Crump, A. D., Eitel, P., \& Saylor, K. E. (2001). Peer and parent influences on smoking and drinking among early adolescents. Health Education and Behaviour 28, 95-107.

Susman, E. J., \& Rogol, A. (2004). Puberty and psychological development. In R. Lerner \& L. Steinberg (Eds). Handbook of adolescent psychology. New York Wiley.

Susman, E. J., Dorn, L. D., \& Schiefelbein, V. L. (2003). Puberty, sexuality and health. In I.B. Weiner (Ed). Handbook of psychology (Vol vi)). New York: Wiley.

Tucker, J. S., Ellickson, P. L., \& Klein, M. S. (2003). Predictive of the transition to regular smoking during adolescence and young adulthood. Journal of Adolescent Health 32, 314-324.

Ward, L. M., \& Caruthers, A. (2001). Media influences. In J. Worell (Ed), Encyclopedia of women and gender. San Diego: Academic Press.

Ward, L. M. (2003). Understanding the role of entertainment media in the sexual socialization of American youth: A review of empirical research development review. 23, 347-388.

Weincke, J. K., Thurston, S. W., Kelsey, K. T., Varkony, A., Wain, J. C., Mark, E. J., \& Christian, D. C. (1999). Early age at smoking initiation and tobacco carcinogen DNA damage in the lung. Journal of the National Cancer institute. 91, 614-619.

Wright, M. R. (1989). Body image satisfaction in adolescent girls and boys. Journal of Youth and Adolescence, 18, 71-84. 